\title{
Effects of dietary tributyrin on intestinal mucosa development, mitochondrial function and AMPK-mTOR pathway in weaned pigs
}

Chunchun Wang ${ }^{1}$, Shuting Cao ${ }^{1}$, Zhuojun Shen ${ }^{1}$, Qihua Hong ${ }^{1}$, Jie Feng ${ }^{1}$, Yan Peng ${ }^{2}$ and Caihong Hu ${ }^{1 *}$ (1)

\begin{abstract}
Background: The objective of this experiment was to investigate the influence of dietary tributyrin on intestinal mucosa development, oxidative stress, mitochondrial function and AMPK-mTOR signaling pathway.

Methods: Seventy-two pigs were divided into two treatments and received either a basal diet or the same diet supplemented with $750 \mathrm{mg} / \mathrm{kg}$ tributyrin. Each treatment has six replicates of six pigs. After 14 days, 6 pigs from each treatment were selected and the jejunal samples were collected.
\end{abstract}

Results: Results showed that supplemental tributyrin increased $(P<0.05)$ villus height and villus height: crypt depth of weaned pigs. Pigs fed tributyrin had greater $(P<0.05)$ RNA/DNA and protein/DNA ratios than pigs on the control group. The mRNA levels of sodium glucose transport protein-1 and glucose transporter-2 in the jejunum were upregulated $(P<0.05)$ in pigs fed the tributyrin diet. Dietary tributyrin supplementation lowered $(P<0.05)$ the malondialdehyde and hydrogen peroxide $\left(\mathrm{H}_{2} \mathrm{O}_{2}\right)$ content in jejunum, enhanced $(P<0.05)$ the mitochondrial function, as demonstrated by decreased $(P<0.05)$ reactive oxygen species level and increased $(P<0.05)$ mitochondrial membrane potential. Furthermore, tributyrin increased $(P<0.05)$ mitochondrial DNA content and the mRNA abundance of genes related to mitochondrial functions, including peroxisomal proliferator-activated receptor- $\gamma$ coactivator-1a, mitochondrial transcription factor $A$, nuclear respiratory factor-1 in the jejunum. Supplementation with tributyrin elevated $(P<0.05)$ the phosphorylation level of AMPK and inhibited $(P<0.05)$ the phosphorylation level of mTOR in jejunum compared with the control group.

Conclusions: These findings suggest that dietary supplementation with tributyrin promotes intestinal mucosa growth, extenuates oxidative stress, improves mitochondrial function and modulates the AMPK-mTOR signal pathway of weaned pigs.

Keywords: AMPK-mTOR signaling pathway, Intestinal mucosa development, Mitochondrial function, Tributyrin, Weaned pigs

\footnotetext{
* Correspondence: chhu@zju.edu.cn

${ }^{1}$ Key Laboratory of Molecular Animal Nutrition, Ministry of Education, Animal Science College, Zhejiang University, Yu Hang Tang Rd No. 866, Hangzhou 310058, People's Republic of China

Full list of author information is available at the end of the article
}

(c) The Author(s). 2019 Open Access This article is distributed under the terms of the Creative Commons Attribution 4.0 International License (http://creativecommons.org/licenses/by/4.0/), which permits unrestricted use, distribution, and reproduction in any medium, provided you give appropriate credit to the original author(s) and the source, provide a link to the Creative Commons license, and indicate if changes were made. The Creative Commons Public Domain Dedication waiver (http://creativecommons.org/publicdomain/zero/1.0/) applies to the data made available in this article, unless otherwise stated. 


\section{Background}

Piglets are often subjected to nutritional, physiological and immunological stresses during the weaning process [1]. It has been determined that weaning can quickly lead to the intestinal-mucosal injury, such as villus atrophy and crypt hyperplasia and further impair intestinal absorption function [2-5]. Butyrate, as a SCFA (short chain fatty acid), has gained much attention due to its rewarding effects on cellular energy metabolism and intestinal homeostasis [6]. Butyrate is rapidly absorbed across the luminal membranes of intestinal epithelial cells under the action of butyrate transporters [7]. Substantial evidence has reported that butyrate plays a potential role in affecting epithelial cell growth and differentiation, and repairing intestinal injury [8-10]. Tributyrin, containing three molecules of butyrate, has also been reported to maintain intestinal mucosa normal function $[11,12]$. Therefore, it is necessary to study the beneficial effects of butyrate or tributyrin on intestinal development and absorption function in weaned piglets.

The intestine requires a lot of energy to renew and repair the damaged intestinal mucosa [13], and mitochondria are responsible for the main source of cellular energy [14]. Mitochondria are the primary site of reactive oxygen species (ROS) generation, and at the same time, they are highly susceptible to ROS [15]. Our previous study has found that weaning caused oxidative stress and severely impaired mitochondrial function [16]. Recently, Xing et al. [17] reported that in HepG2 cells, sodium butyrate alleviated oxidative injury and enhanced mitochondrial function. Besides, several papers reported that butyrate was effective in relieving intestinal oxidative stress $[18,19]$. Nevertheless, no information is available about the effects of butyrate or tributyrin on oxidative stress and mitochondrial function of intestine in weaned pigs.

AMPK (AMP-activated protein kinase), a sensor of energy state, is responsible for regulating mitochondrial function and cell energy metabolism [20]. Activation of AMPK results in the inhibition of mTOR (mammalian target of rapamycin), a downstream regulator of AMPK that senses energy and stress [21]. Substantial evidence has suggested that the AMPKmTOR pathway acted as an important role in modulating oxidative stress [22-24]. However, the effect of butyrate or tributyrin on AMPK-mTOR pathway has not been reported so far.

Accordingly, we hypothesized that dietary tributyrin could enhance intestinal mucosa development, improve mitochondrial function and influence AMPK-mTOR signaling pathway of weaned pigs. Our objective was aimed at exploring the effect of dietary tributyrin on intestinal mucosa growth, mitochondrial function as well as AMPK-mTOR signaling pathway of weaned pigs.

\section{Methods}

\section{Experimental design}

Seventy-two pigs (Duroc $\times$ Landrace $\times$ Yorkshire, body weight (BW) of $6.8 \mathrm{~kg}$, weaned at $24 \pm 1$ days of age), were divided into two treatments according to their initial BW and sex. Each treatment has six replicates of six pigs ( 3 barrows and 3 gilts). Two treatments received basal diet or the same diet supplemented with $750 \mathrm{mg} / \mathrm{kg}$ tributyrin (provided by Shanghai Menon Feed Co. Ltd., Shanghai, China). The formula for the diets is in compliance with NRC (2012) (Table 1). Pigs had free to drink and feed.

\section{Sample collection}

After 14 days, 6 pigs (3 barrows and 3 gilts) from each treatment ( 1 pig per pen) were euthanized with an ear intravenous injection of sodium pentobarbital $(200 \mathrm{mg} /$ $\mathrm{kg}$ BW) (Sigma-Aldrich, St. Louis, MO) and the gastrointestinal tract was rapidly removed. Proximal jejunal samples were fixed in $4 \%$ paraformaldehyde for

Table 1 Ingredient and composition of diets on an as-fed basis

\begin{tabular}{|c|c|}
\hline \multicolumn{2}{|l|}{ Item } \\
\hline \multicolumn{2}{|l|}{ Ingredients, g/kg } \\
\hline Corn & 455 \\
\hline Wheat middling & 80 \\
\hline Soybean meal & 170 \\
\hline Fish meal & 30 \\
\hline Spray-dried plasma protein & 30 \\
\hline Dried whey & 150 \\
\hline Soybean oil & 15 \\
\hline Dicalcium phosphate & 6 \\
\hline Limestone & 5 \\
\hline Sodium chloride & 1 \\
\hline L-Lysine $\mathrm{HCl}$ & 5 \\
\hline DL-Methionine & 1.2 \\
\hline L-threonine & 1.7 \\
\hline Sucrose & 30 \\
\hline Vitamin-mineral premix ${ }^{a}$ & 20.1 \\
\hline \multicolumn{2}{|l|}{ Analyzed composition, $\mathrm{g} / \mathrm{kg}$} \\
\hline Digestible energy ${ }^{\mathrm{b}}, \mathrm{MJ} / \mathrm{kg}$ & 14.9 \\
\hline Crude protein & 203.4 \\
\hline Lysine & 14.3 \\
\hline Methionine & 4.7 \\
\hline Calcium & 6.9 \\
\hline Total phosphorus & 6.2 \\
\hline \multicolumn{2}{|c|}{$\begin{array}{l}\text { aProvided the following per kilogram of diet: vitamin } A, 8750 \mathrm{IU} \text {; vitamin } \mathrm{D}_{3} \text {, } \\
2500 \mathrm{IU} \text {; vitamin } \mathrm{E}, 25 \mathrm{IU} \text {; vitamin } \mathrm{K}_{3}, 2.5 \mathrm{mg} \text {; vitamin } \mathrm{B}_{1}, 2.5 \mathrm{mg} \text {; vitamin } \mathrm{B}_{2} \text {, } \\
6.25 \mathrm{mg} \text {; vitamin } \mathrm{B}_{6}, 2.5 \mathrm{mg} \text {; vitamin } \mathrm{B}_{12}, 25 \mu \mathrm{\mu g} \text {; } \mathrm{B} \text {-Biotin, } 100 \mu \mathrm{gg} \text {; folic acid, } \\
1.25 \mathrm{mg} \text {; nicotinamide, } 25 \mathrm{mg} ; D \text {-pantothenic acid, } 12.5 \mathrm{mg} ; \mathrm{Zn}, 80 \mathrm{mg} ; \mathrm{Fe}, 80 \\
\mathrm{mg} ; \mathrm{Cu}, 20 \mathrm{mg} ; \mathrm{Mn}, 40 \mathrm{mg} ; \mathrm{l}, 0.15 \mathrm{mg} \text {; Se, } 0.3 \mathrm{mg} ; \mathrm{Co}, 0.3 \mathrm{mg} \\
\text { bDigestible energy was calculated from data provide by Feed Database in } \\
\text { China (2012) }\end{array}$} \\
\hline
\end{tabular}

Item

Ingredients, g/kg

Corn 455

a Provided the following per kilogram of diet: vitamin $A_{1} 8750 \mathrm{IU}$; vitamin $\mathrm{D}_{3}$ $\mathrm{K}_{3}, 2.5 \mathrm{mg}$; vitamin $\mathrm{B}_{1}, 2.5 \mathrm{mg}$; vitamin $\mathrm{B}_{2,}$ $1.25 \mathrm{mg}$; nicotinamide, $25 \mathrm{mg}$; $D$-pantothenic acid, $12.5 \mathrm{mg} ; \mathrm{Zn}, 80 \mathrm{mg} ; \mathrm{Fe}, 80$ China (2012) 
measurement of intestinal mucosa architecture. Segments of the proximal jejunum were immediately gained to isolate intestinal mitochondria. The mucosa from the adjacent jejunum were harvested and placed in liquid nitrogen for further analysis.

\section{Measurement of intestinal mucosa architecture}

Segments for morphological study were fixed in $4 \%$ paraformaldehyde and then embedded in paraffin wax. Sections of $5 \mu \mathrm{m}$ were cut and stained with hematoxylin and eosin. Crypt depth and villus height were measured in three intestinal cross sections with at least 10 welloriented crypt villus units for each cross-section using an image processing and analysis system (Leica Imaging Systems, Cambridge, UK) and averaged for each sample.

\section{Measurement of mucosal DNA, RNA and protein}

The jejunal DNA, RNA and protein were collected from snap-frozen mucosal samples, with TRI Reagent-RNA/ DNA/Protein isolation reagent (TaKaRa Biotechnology, Dalian, China). The concentrations were measured according to Jiao et al. [25].

\section{Determination of antioxidative enzyme activities}

Antioxidant parameters, including superoxide dismutase (SOD), catalase (CAT), malondialdehyde (MDA) and hydrogen peroxide $\left(\mathrm{H}_{2} \mathrm{O}_{2}\right)$ in jejunum were determined with commercially available kits (Nanjing Jiancheng Bioengineering Institute, Nanjing, China).

\section{Isolation of mitochondria}

Fresh jejunal mucosa was prepared to isolate mitochondria. The process was in compliance with the rules of mitochondria isolation kit (Beyotime Institute of Biotechnology). After intestinal mucosa was homogenized in MSH buffer $(10 \mathrm{mmol} / \mathrm{L}$ HEPES, $\mathrm{pH} 7.5$, containing $200 \mathrm{mmol} / \mathrm{L}$ mannitol, $70 \mathrm{mmol} / \mathrm{L}$ sucrose, $1.0 \mathrm{mmol} / \mathrm{L}$ egtazic acid and $2.0 \mathrm{mg} / \mathrm{mL}$ serum albumin), the homogenate was centrifuged at $1000 \times g$ for $10 \mathrm{~min}$ at $4{ }^{\circ} \mathrm{C}$. And then the collected supernatant was centrifuged at $3500 \times g$ for $10 \mathrm{~min}$ at $4{ }^{\circ} \mathrm{C}$ to acquire mitochondrial pellet [26].

\section{Mitochondrial reactive oxygen species (ROS) content}

The fluorescent probes $\left(2^{\prime}, 7^{\prime}\right.$-dichlorohydro-fluorescein diacetate, DCFH-DA) were used for detecting mitochondria ROS content as previously described [27]. DCFHDA can pass through the cell membrane and be hydrolyzed into DCFH. ROS can oxidize non-fluorescent DCFH into DCF, which has a maximum absorption peak at an excitation wavelength of $485 \mathrm{~nm}$ and an emission wavelength of $525 \mathrm{~nm}$, and the intensity is proportional to the level of ROS. The fluorescence of DCF was assayed using a fluorescence microplate reader (FLx800,
Bio-Tek Instruments, Inc.). The results were indicated as fold changes of the control.

\section{Mitochondrial membrane potential $\left(\Delta \Psi_{\mathrm{m}}\right)$}

The changes of $\Delta \Psi \mathrm{m}$ were assayed by $\Delta \Psi \mathrm{m}$ assay kit with JC-1 (Beyotime Institute of Biotechnology). The isolated mitochondria were strained with $\mathrm{JC}-1$ at $37^{\circ} \mathrm{C}$ for $15 \mathrm{~min}$, and then the fluorescence intensity was assayed using a fluorescence microplate reader (FLx800, Bio-Tek Instruments, Inc.). JC-1 monomer form (green) fluorescence was excited at $485 \mathrm{~nm}$, and the emission was detected at $530 \mathrm{~nm}$. JC-1 aggregate form (red) fluorescence was excited at $485 \mathrm{~nm}$, and emission fluorescence was detected at $590 \mathrm{~nm}$. The ratio of red and green fluorescence values was used to reflect the $\Delta \Psi \mathrm{m}[16]$.

\section{Determination of mitochondrial DNA (mtDNA) content}

The mtDNA numbers relative to genomic DNA were assayed with co-amplification of the mitochondrial DNAloop ( $m t$ D-loop) and the nuclear-encoded $\beta$-actin gene using RT- PCR according to the previous steps [28]. Total DNA was extracted from proximal jejunal mucosa using a TIANamp Stool DNA Kit (Tiangen Biotech, Beijing, China). For the $m t$ D-loop the primers were forward 5'-GATCGT ACATAGCACATATCATGTC-3', reverse 5'-GGTCCT GAAGTAAGAACCAGATG-3'. For $\beta$-actin the primers were forward 5'-CCССТCСТCTCTTGCСТCTC-3', reverse 5' - AAAAGTCCTAGGAAAATGGCAGAAG-3.

\section{mRNA expressions of nutrient transporter genes and mitochondrial function-related genes}

Total RNA of jejunal mucosa was obtained with the Trizol reagent (TaKaTa, Dalian, China) according to the kit's direction. RNA concentration and purity were assayed by a Nano Drop spectrophotometer (ND-2000; NanoDrop Technologies, Wilmington, DE). Reverse transcription was performed with the PrimeScripte RT reagent kit (TaKaRa Biotechnology, Dalian, China). Quantitative RT-PCR was performed on a StepOne Plus real-time PCR system (Applied Biosystems, Foster City, CA) using SYBR Green Master mix (Promega, Madison, WI) as described by Liu et al. [29]. The genes include sodium glucose transport protein-1 (SGLT1), glucose transporter-2 (GLUT2), $\mathrm{Na}^{+}$-dependent neutral amino acid transporter 2 (ASCT2), $\mathrm{y}^{+}$L-type amino acid transporter $1\left(y^{+} L A T 1\right)$, dipeptide transporter 1 (PepT1), peroxisomal proliferator-activated receptor- $\gamma$ coactivator- $1 \alpha$ $(P G C-1 \alpha)$, mitochondrial transcription factor A (TFAM) and nuclear respiratory factor-1(NRF-1). Primers are exhibited in Table 2. The $\beta$-actin was used as a reference gene to normalize mRNA levels of each target gene. The $2^{-\Delta \Delta \mathrm{Ct}}$ method was used to analyze the relative expression, calculated relative to the values from the control group. 
Table 2 Primers used for real-time quantitative PCR

\begin{tabular}{|c|c|c|c|}
\hline Primer name & Primer sequence & Size, bp & Accession numbers \\
\hline$\overline{S G L T 1}$ & $\begin{array}{l}\text { F:5'-TCATCATCGTCCTGGTCGTCTC-3' } \\
\text { R:5'-CTTCTGGGGCTTCTTGAATGTC-3' }\end{array}$ & 144 & M34044.1 \\
\hline GLUT2 & $\begin{array}{l}\text { F:5'-ATTGTCACAGGCATTCTTGTTAGTCA-3' } \\
\text { R:5'-TTCACTTGATGCTTCTTCCCTITC-3' }\end{array}$ & 273 & NM_001097417 \\
\hline ASCT2 & $\begin{array}{l}\text { F:5'-CTGGTCTCCTGGATCATGTGG-3' } \\
\text { R:5'-CAGGAAGCGGTAGGGGTITI-3' }\end{array}$ & 172 & DQ231578.1 \\
\hline$y^{+} L A T 1$ & $\begin{array}{l}\text { F:5'-TTCTCTTACTCGGGCTGGGA-3' } \\
\text { R:5'-GCGCCATGAGACCATTGAAC-3' }\end{array}$ & 400 & EU047705.1 \\
\hline PepT1 & $\begin{array}{l}\text { F:5'-CAGACTTCGACCACAACGGA-3' } \\
\text { R:5'-TTATCCCGCCAGTACCCAGA-3' }\end{array}$ & 99 & NM_214347.1 \\
\hline PGC-1a & $\begin{array}{l}\text { F:5'-CCCGAAACAGTAGCAGAGACAAG-3' } \\
\text { R:5'-CTGGGGTCAGAGGAAGAGATAAAG-3' }\end{array}$ & 111 & NM_213963.2 \\
\hline TFAM & $\begin{array}{l}\text { F:5'-GGTCCATCACAGGTAAAGCTGAA-3' } \\
\text { R:5'-ATAAGATCGTITCGCCCAACTTC-3' }\end{array}$ & 167 & AY923074.1 \\
\hline NRF-1 & $\begin{array}{l}\text { F:5'-GCCAGTGAGATGAAGAGAAACG-3' } \\
\text { R:5'-CTACAGCAGGGACCAAAGTTCAC-3' }\end{array}$ & 166 & AK237171.1 \\
\hline$\beta$-actin & $\begin{array}{l}\text { F:5'-GGATGCAGAAGGAGATCACG-3' } \\
\text { R:5'-ATCTGCTGGAAGGTGGACAG-3' }\end{array}$ & 130 & DQ845171.1 \\
\hline
\end{tabular}

SGLT1: sodium-glucose transporter 1; GLUT2: glucose transporter type 2; ASCT2: $\mathrm{Na}^{+}$-dependent neutral amino acid transporter 2; $\mathrm{y}^{+}$LAT1: $\mathrm{y}^{+} \mathrm{L}_{\text {-type amino acid }}$ transporter 1; PepT1: dipeptide transporter 1; PGC-1a: peroxisomal proliferator-activated receptor- $\gamma$ coactivator-1a; TFAM: mitochondrial transcription factor A; NRF-1: nuclear respiratory factor-1

\section{Western blot assay}

The steps are in accordance with the procedures of $\mathrm{Hu}$ et al. [5]. Sample in the jejunal mucosa was performed with SDS-PAGE and transferred to PVDF membranes. The membrane was blocked for $120 \mathrm{~min}$ at $25^{\circ} \mathrm{C}$, and then incubated with primary antibodies overnight at $4{ }^{\circ} \mathrm{C}$. The membrane was rinsed and then incubated with the secondary antibodies for $60 \mathrm{~min}$ at $25^{\circ} \mathrm{C}$. The antibodies, including $\mathrm{p}$-AMPK, AMPK, p-mTOR, mTOR, GAPDH and HRP-conjugated anti-rabbit Ab were purchased in Santa Cruz Technology Inc. (Santa Cruz, CA). The signal was displayed with Chemi Scope 3400 (ClinxScience Instruments, Shanghai, China) and the protein band value was counted with Image $\mathrm{J}$ analysis software.

\section{Statistical analysis}

Data were analyzed by Student's $t$-test with SPSS 22.0 statistical package (SPSS Inc., Chicago, IL). The significance value and a trend toward difference were set at levels of $P<0.05$ and $P<0.10$, respectively.

\section{Results}

\section{Effect of tributyrin on jejunal mucosa architecture of} weaned pigs

Intestinal mucosa architecture is exhibited in Table 3. The weaning pigs fed with tributyrin showed higher $(P<$ $0.05)$ jejunal villus height and villus height: crypt depth in comparison to the control. The crypt depth had no difference in two treatments $(P>0.05)$.

\section{Effect of tributyrin on jejunal DNA, RNA and protein of weaned pigs}

Data about the concentrations of DNA, RNA and protein of weaned pigs are summarized in Table 4. Tributyrin increased $(P<0.05)$ jejunal RNA/DNA ratio as well as protein/DNA ratio in weaned pigs. No alteration was observed in the DNA concentrations between the two groups.

\section{Effect of tributyrin on jejunal mRNA expression of nutrient transporter of weaned pigs}

As shown in Table 5, dietary tributyrin induced an increase $(P<0.05)$ in SGLT1 and GLUT2 mRNA level, and had a trend $(P<0.1)$ to raise mRNA level of ASCT2 in the jejunal mucosa of weaned pigs.

Table 3 Effects of tributyrin on jejunal mucosa architecture of weaned pigs

\begin{tabular}{lllll}
\hline Item & Control & Tributyrin & SEM & $P$ \\
\hline Villus height, $\mu \mathrm{m}$ & 384.29 & 444.53 & 8.37 & 0.001 \\
Crypt depth, $\mu \mathrm{m}$ & 245.88 & 222.34 & 9.57 & 0.113 \\
Villus height: Crypt depth & 1.58 & 2.02 & 0.09 & 0.007 \\
\hline
\end{tabular}

Values are mean and pooled SEM, $n=6$

Differences were considered significant at $P<0.05$ 
Table 4 Effects of tributyrin on DNA, RNA and protein concentrations in the jejunum of weaned pigs

\begin{tabular}{lllll}
\hline Item & Control & Tributyrin & SEM & $P$ \\
\hline DNA, mg/g & 0.61 & 0.67 & 0.05 & 0.373 \\
RNA/DNA, g/g & 5.54 & 6.97 & 0.33 & 0.012 \\
Protein/DNA, g/g & 94.57 & 117.55 & 4.40 & 0.004
\end{tabular}

Values are mean and pooled SEM, $n=6$

Differences were considered significant at $P<0.05$

\section{Effects of tributyrin on jejunal antioxidant indicators of weaned pigs}

Table 6 indicates that the contents of MDA and $\mathrm{H}_{2} \mathrm{O}_{2}$ in jejunum were reduced $(P<0.05)$ in pigs fed tributyrin compared to those in control. However, no significant alteration $(P>0.05)$ was observed in activities of SOD and CAT of jejunum between the two groups.

\section{Effect of tributyrin on jejunal mitochondrial ROS and $\Delta \Psi$ of weaned pigs}

Figure 1 shows that in comparison with the control, tributyrin significantly reduced $(P<0.05)$ mitochondrial ROS level and raised $(P<0.05) \Delta \Psi$.

\section{Effect of tributyrin on jejunal mRNA expression of} mitochondrial function-related genes of weaned pigs Figure 2 shows that tributyrin increased $(P<0.05)$ mtDNA copy numbers as well as mRNA levels of mitochondrial function-related genes, including $P G C-1 \alpha$, TFAM and NRF-1.

\section{Effect of tributyrin on AMPK-mTOR signaling pathway in the jejunum of weaned piglets}

Figure 3 shows the effect of tributyrin on the AMPKmTOR signaling pathway. Compared to the control, supplemental tributyrin effectively elevated $(P<0.05)$ the ratio of the phosphorylated AMPK to total AMPK (p-AMPK/ AMPK), while decreased $(P<0.05)$ the ratio of the phosphorylated mTOR to total mTOR (p-mTOR/mTOR).

Table 5 Effects of tributyrin on mRNA levels of nutrient transporter genes in jejunum of weaned pigs

\begin{tabular}{lllll}
\hline Item $^{\text {a }}$ & Control & Tributyrin & SEM & $P$ \\
\hline SGLT1 & 1.00 & 1.97 & 0.16 & 0.002 \\
GLUT2 & 1.00 & 1.68 & 0.17 & 0.017 \\
ASCT2 & 1.00 & 1.52 & 0.18 & 0.075 \\
$y^{+}$LAT1 & 1.00 & 1.27 & 0.16 & 0.275 \\
PepT1 & 1.00 & 1.31 & 0.15 & 0.183 \\
\hline
\end{tabular}

${ }^{a}$ SGLT1: sodium-glucose transporter 1; GLUT2: glucose transporter type 2; ASCT2: $\mathrm{Na}^{+}$-dependent neutral amino acid transporter 2; $\mathrm{y}^{+}$LAT1: $\mathrm{y}^{+} \mathrm{L}$-type amino acid transporter 1; PepT1: dipeptide transporter 1

Values are mean and pooled SEM, $n=6$

Differences were considered significant at $P<0.05$
Table 6 Effects of tributyrin on antioxidant indicators in the jejunum of weaned pigs

\begin{tabular}{lllll}
\hline Item $^{\text {a }}$ & Control & Tributyrin & SEM & $P$ \\
\hline SOD, U/mg protein & 58.21 & 67.36 & 3.28 & 0.076 \\
CAT, U/mg protein & 8.72 & 10.17 & 0.79 & 0.221 \\
MDA, nmol/g protein & 0.65 & 0.31 & 0.08 & 0.014 \\
$\mathrm{H}_{2} \mathrm{O}_{2}, \mathrm{mmol} / \mathrm{g}$ protein & 17.38 & 12.48 & 1.27 & 0.021
\end{tabular}

a $S O D$ superoxide dismutase, CAT catalase; MDA malondialdehyde; $\mathrm{H}_{2} \mathrm{O}_{2}$ hydrogen peroxide

Values are mean and pooled SEM, $n=6$

Differences were considered significant at $P<0.05$

\section{Discussion}

Weaning pigs are often confronted with changes of intestinal architecture, including villus atrophy and crypt hyperplasia [5]. Butyrate, a volatile fatty acid, plays a significant part in enhancing intestinal mucosa architecture and promoting intestinal growth [30]. This current study demonstrated that tributyrin increased villus height as well as villus height: crypt depth, suggesting that weaning-induced injury to jejunal mucosa architecture was alleviated by addition with tributyrin. Similar to our results, Dong et al. [11] showed that in the intrauterine growth restriction pigs, dietary tributyrin increased villus height: crypt depth of the duodenum and jejunum, and lowed crypt depth of duodenum. The protein level, the ratio of RNA to DNA and protein to DNA in the intestinal mucosa are valuable biological parameters to assess intestinal growth and development [25, 31]. DNA concentration represents the mitosis rate to renew columnar epithelial cell, RNA/DNA and protein/DNA signifies cell efficiency and protein synthesis efficiency, respectively [25]. In this research, dietary tributyrin elevated the jejunal RNA/DNA and protein/DNA, which is beneficial for the small intestinal growth of weaned pigs. Similarly, another study found that SCFAs were trophic to the intestinal mucosa as evidenced by the increased DNA, RNA and protein concentration in intestinal mucosa of rats [32]. Monocarboxylate transporter 1 (MCT-1) plays an important role in the transport of monocarboxylates across cell membrane [33]. It has been identified in the small intestine [34] and colon [35]. An earlier research reported that in cultured colonic epithelial cells, treatment with sodium butyrate caused a concentration- and time-dependent upregulation of MCT1 mRNA and protein [36]. These results indicated that dietary tributyrin may enhance the expression of butyrate transporters in the jejunum, thereby promoting the intestinal mucosa development.

Weaned piglets need a huge amount of nutrients to meet the rapid renewal and growth of the intestine. The absorption of nutrients mainly depends on specific transporters that transport nutrients across the intestinal epithelium [4]. However, few researches studied the 

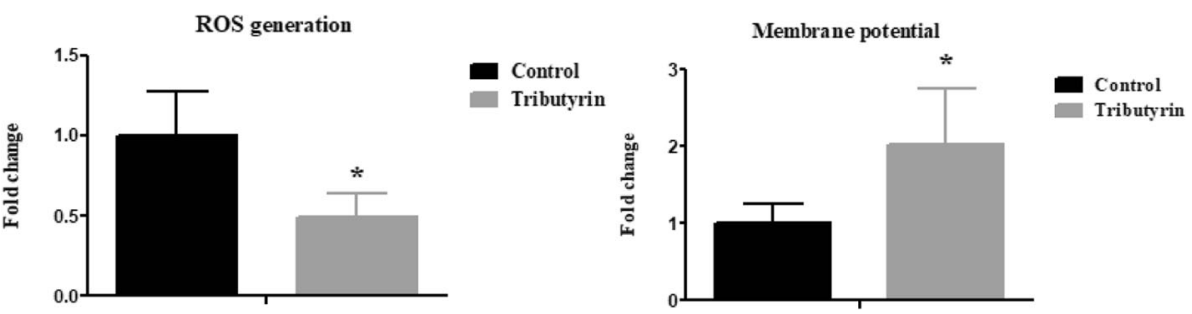

Fig. 1 Effects of tributyrin on mitochondrial ROS production and $\Delta \psi m$ in jejunum of weaned pigs. Values are means and SD represented by vertical bars. *Differences were considered significant at $P<0.05$. The ROS production and $\Delta \psi m$ were expressed as fold changes, calculated relative to the control group. ROS: reactive oxygen species; $\Delta \psi \mathrm{m}$ : mitochondrial membrane potential

action of tributyrin in intestine absorption function of weaned pigs. Therefore, we observed the effects of tributyrin on mRNA expressions of intestinal nutrient transporters (SGLT1, GLUT2, ASCT2, $y^{+} L A T 1$, PepT1). SGLT1 is a rate-limiting step to transport glucose into the absorptive enterocyte, and GLUT2 transported glucose from intestinal cell into the blood circulation [37]. ASCT2 and LAT1, in charge for transporting neutral amino acid, have a principal part in the growth and proliferation of intestinal cell [38]. PepT1, widely existed in intestinal epithelial cell, is responsible to transport dipeptide from the lumen into enterocyte [39]. In present study, we found that the jejunal SGLT1 and GLUT2 mRNA abundances were elevated by tributyrin. The result was analogous with an in vitro study using Caco-2, which found that butyrate treatment elevated the mRNA level of GLUT2 [40]. Weaning piglets were confronted with innutrition and intestinal disorders due to the immature digestion and absorption systems [1], which might be part of the reason why tributyrin can promote the mRNA expressions of the nutrient transporters of weaning piglets. Accordingly, it is likely that tributyrin enhanced absorption function, thus transporting more nutrition to improve the intestinal mucosa architecture.

Several studies reported that tributyrin reduced intestinal oxidative stress in the ethanol-challenged colitis [41] and colon of dextran sodium sulphate-challenged mice [42]. However, there was little evidence about the antioxidant effect of tributyrin in pigs. Therefore, it is necessary to assess the effect of tributyrin on redox state in intestine of weaned pigs. Generally, CAT and SOD are regarded as two main antioxidant enzymes and have essential roles in the prevention of oxidative injury. Surprisingly, we found that dietary tributyrin had no significant effects on enzyme activities of CAT and SOD. However, Leonel et al. [42] found that tributyrin supplementation lowered the $\mathrm{H}_{2} \mathrm{O}_{2}$ level, increased the SOD and CAT activities in dextran sodium sulphate-induced colitis of mice. Ma et al. [18] reported that after treatment with sodium butyrate, the levels of SOD, GSH-Px (glutathione peroxidase) and GSH (glutathione) increased while MDA level decreased in scratched IPEC-J2 cell. This discrepancy could be explained by the diverse trial conditions, animal species and animal model. MDA
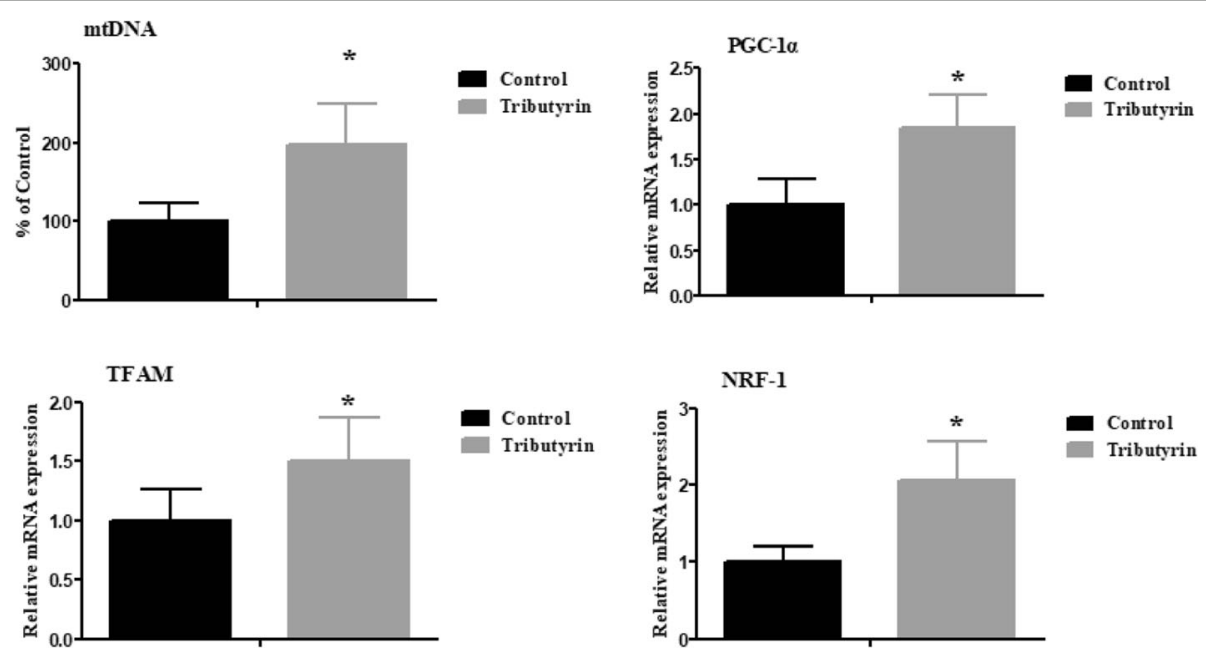

Fig. 2 Effects of tributyrin on mtDNA and mRNA levels of mitochondrial function-related genes of weaned pigs. Values are means and SD represented by vertical bars. *Differences were considered significant at $P<0.05$. mtDNA: mitochondrial DNA; PGC-1a: peroxisomal proliferatoractivated receptor- $\gamma$ coactivator-1 $\alpha$; TFAM: mitochondrial transcription factor A; NRF-1: nuclear respiratory factor-1 


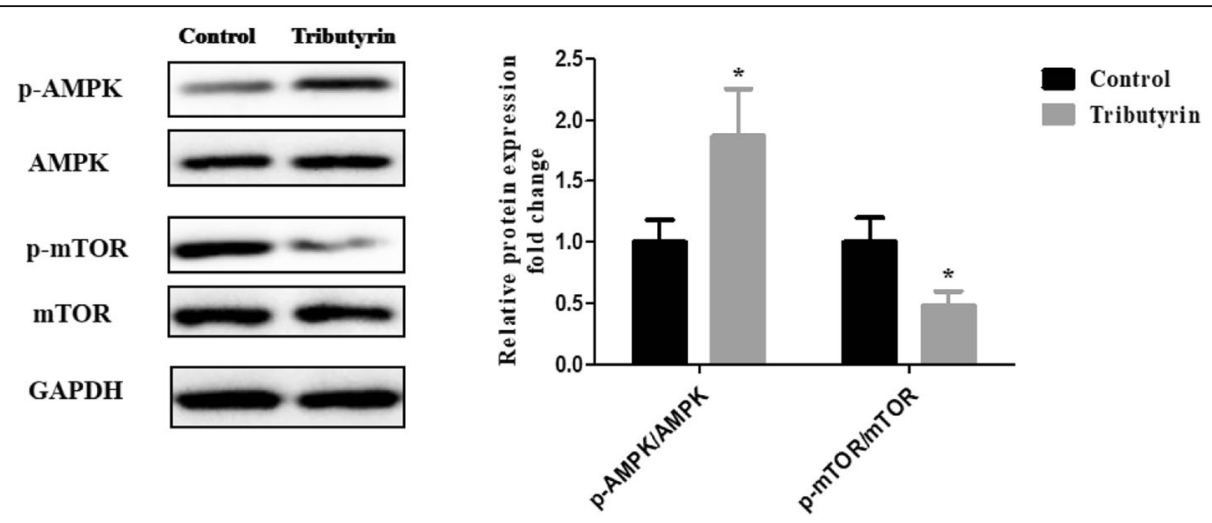

Fig. 3 Effects of tributyrin on AMPK- mTOR signal pathway in jejunum of weaned pigs. The bands are representative blots from one of six pigs. The values are calculated as the ratios of their phosphorylation levels (p-AMPK, p-mTOR) and the total levels. Values are means and SD represented by vertical bars. *Differences were considered significant at $P<0.05$

concentration in tissues and serum has been considered as biomarkers of oxidative injury [43]. In our study, the results showed that dietary tributyrin decreased MDA and $\mathrm{H}_{2} \mathrm{O}_{2}$ level, which indicates that tributyrin relieved the intestinal oxidative stress of weaned pigs.

Weaning often causes oxidative stress and then damages mitochondria [16]. As a result, damaged mitochondria release more ROS and then lead to $\Delta \Psi \mathrm{m}$ collapse by the formation of permeability transition [44]. Therefore, higher mitochondrial ROS and lower $\Delta \Psi \mathrm{m}$ are considered to be the markers of mitochondrial dysfunction [45, 46]. Although prior studies have found that butyrate can reduce intestinal oxidative stress, no evidence established the effect on intestinal mitochondrial function of pigs. In this experiment, we observed that tributyrin reduced mitochondrial ROS level and increased $\Delta \Psi \mathrm{m}$ of jejunum in comparison to the control. The findings suggested that tributyrin mitigated oxidative damage and enhanced mitochondria function. A previous study also found that, in high fat diet-induced obese mice, butyrate improved mitochondrial function reflected by the enhanced mitochondrial oxidative phosphorylation [47]. Li et al. [48] found butyrate inhibited the decrease of $\Delta \Psi \mathrm{m}$ in LPS-challenged cow mammary epithelial cell. Davis et al. [49] reported that butyrate reduced the mitochondrial ROS by increasing proton leak through upregulation of uncoupling protein 2 . Russo et al. [19] demonstrated that in intestinal epithelial cells, butyrate was effective in controlling the increase of ROS levels in response to lipopolysaccharide.

The mtDNA was known to function significantly in oxidative phosphorylation and normal mitochondrial function [50]. The mtDNA content can reflect the mitochondrial function [50]. In this research, the mtDNA content of piglets fed tributyrin was higher than pigs in control, which was supported by Xing et al. [17], who reported that sodium butyrate restored the $\mathrm{H}_{2} \mathrm{O}_{2}$-induced decrease of mtDNA copy number in HepG2 cells. The result indicates that dietary tributyrin is quite helpful in attenuating mtDNA damage and improving mitochondrial function of weaned piglets. The alteration of mtDNA content is in accordance with the changes of multiple transcriptional key regulators involved in mitochondrial biogenesis [51]. $P G C-1 \alpha$ is proven to be a major regulator of mitochondrial biogenesis [52]. NRF-1 and TFAM are crucial for governing mtDNA replication and transcription during mitochondria biogenesis [53]. In the present study, the upregulated NRF-1, PGC-1 $\alpha$ and TFAM mRNA abundances were observed in the jejunum of pigs fed tributyrin. Similarly, a previous study found that in oxidative injured HepG2 cells, sodium butyrate increased $P G C-1 \alpha$ and TFAM mRNA levels [17]. Thus, tributyrin plays a relevant role in improving mitochondrial function of weaned pigs.

AMPK, a key energy sensor, functions in the regulation of cellular energy [54]. It has been shown that the activation of AMPK significantly modulates oxidative stress and mitochondrial function [55, 56]. Furthermore, AMPK activation inhibits mTOR, a serine/threonine protein kinase [21]. A large body of evidence suggest that the AMPK-mTOR pathway participated in the regulation of oxidative stress [22-24]. Wherefore, it is essential to investigate the effect of tributyrin on AMPK-mTOR signaling pathway. Our results revealed for the first time that tributyrin elevated the phosphorylation of AMPK and reduced phosphorylation of $\mathrm{mTOR}$ in intestine of pigs. These findings are consistent with previous results where SCFAs stimulate AMPK and inhibit mTOR in human colon cancer cells [57]. Similarly, Mollica et al. [58] found that in insulin-resistant obese mice, sodium butyrate increased liver AMPK activity, reduced ROS generation and improved mitochondrial function. 


\section{Conclusions}

To summarize, the current experiment proved that dietary supplementation with tributyrin enhances intestinal mucosa architecture, promotes the intestinal growth, extenuates oxidative stress and modulates the AMPKmTOR signal pathway of weaned pigs.

\begin{abstract}
Abbreviations
AMPK: AMP-activated protein kinase; ASCT2: $\mathrm{Na}^{+}$-dependent neutral amino acid transporter 2; BW: Body weight; CAT: Catalase; DCFH-DA: 2',7'dichlorohydro-fluorescein diacetate; GLUT2: Glucose transporter-2; GSH: Glutathione; GSH-Px: Glutathione peroxidase; $\mathrm{H}_{2} \mathrm{O}_{2}$ : Hydrogen peroxide; MCT-1: Monocarboxylate transporter; MDA: Malondialdehyde; mt Dloop: Mitochondrial DNA-loop; mtDNA: Mitochondrial DNA; mTOR: Mammalian target of rapamycin; NRF-1: Nuclear respiratory factor-1; PepT1: Dipeptide transporter 1; PGC-1a: Peroxisomal proliferator-activated receptor- $\gamma$ coactivator-1a; ROS: Reactive oxygen species; SCFA: Short chain fatty acid; SGLT1: Sodium glucose transport protein-1; SOD: Superoxide dismutase; TFAM: Mitochondrial transcription factor $\mathrm{A}$. $\mathrm{y}^{+} \mathrm{LAT1}$ : $\mathrm{y}^{+} \mathrm{L}$-type amino acid transporter $1 ; \Delta \psi \mathrm{m}$ : mitochondrial membrane potential
\end{abstract}

\section{Acknowledgements}

We are grateful to Dr. Lefei Jiao for her excellent technical assistance and to Huan Wu for the assistance with the animal feed experiment.

\section{Authors' contributions}

Caihong Hu designed and supervised the experiments. Chunchun Wang carried out the experiments and performed statistical data analysis. Shuting Cao, Zhuojun Shen, Qihua Hong, Jie Feng and Yan Peng gave tremendous help in conducting experiments. Chunchun Wang was also in charge of preparing the manuscript. All authors have read and approved the final Manuscript.

\section{Funding}

This research was supported by National Natural Science Foundation of China (31872387), Zhejiang Provincial Natural Science Foundation (Sodium butyrate promotes restoration of intestinal barrier induced by oxidative stress in piglets through AMPK mediated mitophagy) and Zhejiang Provincal Key $R$ \& D Project (2019C02051).

\section{Availability of data and materials}

All data generated or analyzed during this study are available from the corresponding author on reasonable request.

\section{Ethics approval}

All process was completed on the basis of the Guidelines for Care and Use of Laboratory Animals of Zhejiang University and approved by the Animal Ethics Committee of Zhejiang University.

\section{Consent for publication}

Not applicable.

\section{Competing interests}

The authors declare that they have no competing interests.

\section{Author details}

${ }^{1}$ Key Laboratory of Molecular Animal Nutrition, Ministry of Education, Animal Science College, Zhejiang University, Yu Hang Tang Rd No. 866, Hangzhou 310058, People's Republic of China. 'Shanghai Menon Animal Nutrition Technology Co. Ltd., Shanghai 201807, China.

Received: 3 May 2019 Accepted: 11 September 2019 Published online: 25 November 2019

\section{References}

1. Kim JC, Hansen CF, Mullan BP, Pluske JR. Nutrition and pathology of weaned pigs: nutritional strategies to support barrier function in the gastrointestinal tract. Anim Feed Sci Technol. 2012;173(1-2SI):3-16. https:// doi.org/10.1016/j.anifeedsci.2011.12.022.
2. Buddington RK, Elnif J, Puchal-Gardiner AA, Sangild PT. Intestinal apical amino acid absorption during development of the pig. Am J Physiol Regul Integr Comp Physiol. 2001;280(1):R241-7. https://doi.org/10.1152/ajpregu. 2001.280.1. R241.

3. Boudry G, Peron V, Le Huerou-Luron I, Lalles JP, Seve B. Weaning induces both transient and long-lasting modifications of absorptive, secretory, and barrier properties of piglet intestine. J Nutr. 2004;134(9):2256-62. https://doi. org/10.1093/jn/134.9.2256.

4. Wijtten PJ, van der Meulen J, Verstegen MW. Intestinal barrier function and absorption in pigs after weaning: a review. Br J Nutr. 2011;105(7):967-81. https://doi.org/10.1017/S0007114510005660.

5. $\mathrm{Hu} \mathrm{CH}$, Xiao K, Luan ZS, Song J. Early weaning increases intestinal permeability, alters expression of cytokine and tight junction proteins, and activates mitogen-activated protein kinases in pigs. J Anim Sci. 2013;91(3): 1094-101. https://doi.org/10.2527/jas.2012-5796.

6. Guilloteau P, Martin L, Eeckhaut V, Ducatelle R, Zabielski R, Van Immerseel F. From the gut to the peripheral tissues: the multiple effects of butyrate. Nutr Res Rev. 2010;23(2):366-84. https://doi.org/10.1017/S0954422410000247.

7. Cuff MA, Shirazi-Beechey SP. The importance of butyrate transport to the regulation of gene expression in the colonic epithelium. Biochem Soc Trans. 2004;32(Pt 6):1100-2. https://doi.org/10.1042/BST0321100.

8. Salminen S, Bouley C, Boutron-Ruault MC, Cummings JH, Franck A, Gibson $G R$, et al. Functional food science and gastrointestinal physiology and function. Br J Nutr. 1998;80(Suppl 1):S147-71. https://doi.org/10.1079/ BJN19980108.

9. Hu Z, Guo Y. Effects of dietary sodium butyrate supplementation on the intestinal morphological structure, absorptive function and gut flora in chickens. Anim Feed Sci Technol. 2007;132(3-4):240-9. https://doi.org/10. 1016/j.anifeedsci.2006.03.017

10. Ploger S, Stumpff F, Penner GB, Schulzke JD, Gabel G, Martens H, et al. Microbial butyrate and its role for barrier function in the gastrointestinal tract. Ann N Y Acad Sci. 2012;1258:52-9. https://doi.org/10.1111/j.1749-6632. 2012.06553.x.

11. Dong L, Zhong X, He J, Zhang L, Bai K, Xu W, et al. Supplementation of tributyrin improves the growth and intestinal digestive and barrier functions in intrauterine growth-restricted piglets. Clin Nutr. 2016;35(2):399-407. https://doi.org/10.1016/j.clnu.2015.03.002.

12. Nielsen DSG, Jensen BB, Theil PK, Nielsen TS, Knudsen KEB, Purup S. Effect of butyrate and fermentation products on epithelial integrity in a mucussecreting human colon cell line. J Funct Foods. 2018;40(9-17). https://doi. org/10.1016/j.jf.2017.10.023.

13. Liu Y, Wang $X$, Hou Y, Yin Y, Qiu Y, Wu G, et al. Roles of amino acids in preventing and treating intestinal diseases: recent studies with pig models. Amino Acids. 2017;49(8):1277-91. https://doi.org/10.1007/s00726-017-2450-1.

14. Wallace DC. A mitochondrial paradigm of metabolic and degenerative diseases, aging, and cancer: a dawn for evolutionary medicine. Annu Rev Genet. 2005;39: 359-407. https://doi.org/10.1146/annurev.genet.39.110304.095751.

15. Hussain T, Tan B, Yin Y, Blachier F, Tossou MC, Rahu N. Oxidative stress and inflammation: what polyphenols can do for us? Oxidative Med Cell Longev. 2016;2016:7432797. https://doi.org/10.1155/2016/7432797.

16. Cao ST, Wang CC, Wu H, Zhang QH, Jiao LF, Hu CH. Weaning disrupts intestinal antioxidant status, impairs intestinal barrier and mitochondrial function, and triggers mitophagy in piglets. J Anim Sci. 2018;96(3):1073-83. https://doi.org/10.1093/jas/skx062.

17. Xing $X$, Jiang $Z$, Tang $X$, Wang $P$, Li $Y$, Sun $Y$, et al. Sodium butyrate protects against oxidative stress in HepG2 cells through modulating Nrf2 pathway and mitochondrial function. J Physiol Biochem. 2017;73(3SI):405-14. https:// doi.org/10.1007/s13105-017-0568-y.

18. Ma X, Fan PX, Li LS, Qiao SY, Zhang GL, Li DF. Butyrate promotes the recovering of intestinal wound healing through its positive effect on the tight junctions. J Anim Sci. 2012;90(Suppl 4):266-8. https://doi.org/10.2527/jas.50965.

19. Russo I, Luciani A, De Cicco P, Troncone E, Ciacci C. Butyrate attenuates lipopolysaccharide-induced inflammation in intestinal cells and Crohn's mucosa through modulation of antioxidant defense machinery. PLoS One. 2012;7(3):e32841. https://doi.org/10.1371/journal.pone.0032841.

20. $\mathrm{Xu} \mathrm{J,} \mathrm{Ji} \mathrm{J,} \mathrm{Yan} \mathrm{XH.} \mathrm{Cross-talk} \mathrm{between} \mathrm{AMPK} \mathrm{and} \mathrm{mTOR} \mathrm{in} \mathrm{regulating} \mathrm{energy}$ balance. Crit Rev Food Sci Nutr. 2012;52(5):373-81. https://doi.org/10.1080/ 10408398.2010 .500245

21. Wang J, Yang $X$, Zhang J. Bridges between mitochondrial oxidative stress, ER stress and mTOR signaling in pancreatic beta cells. Cell Signal. 2016;28(8): 1099-104. https://doi.org/10.1016/j.cellsig.2016.05.007. 
22. Song J, Huang Y, Zheng W, Yan J, Cheng M, Zhao R, et al. Resveratrol reduces intracellular reactive oxygen species levels by inducing autophagy through the AMPK-mTOR pathway. Front Med. 2018;12(6):697-706. https:// doi.org/10.1007/s11684-018-0655-7.

23. Zhang L, Wei J, Ren L, Zhang J, Wang J, Jing L, et al. Endosulfan induces autophagy and endothelial dysfunction via the AMPK/mTOR signaling pathway triggered by oxidative stress. Environ Pollut. 2017;220(Pt B):843-52. https://doi.org/10.1016/j.envpol.2016.10.067.

24. Li XN, Song J, Zhang L, LeMaire SA, Hou X, Zhang C, et al. Activation of the AMPK-FOXO3 pathway reduces fatty acid-induced increase in intracellular reactive oxygen species by upregulating thioredoxin. Diabetes. 2009;58(10): 2246-57. https://doi.org/10.2337/db08-1512.

25. Jiao LF, Song ZH, Ke YL, Xiao K, Hu CH, Shi B. Cello-oligosaccharide influences intestinal microflora, mucosal architecture and nutrient transport in weaned pigs. Anim Feed Sci Technol. 2014;195:85-91. https://doi.org/10.1016/j.anifeedsci.2014.05.014.

26. Pintana H, Sripetchwandee J, Supakul L, Apaijai N, Chattipakorn N, Chattipakorn S. Garlic extract attenuates brain mitochondrial dysfunction and cognitive deficit in obese-insulin resistant rats. Appl Physiol Nutr Metab. 2014;39(12):1373-9. https://doi.org/10.1139/ apnm-2014-0255.

27. Cao S, Shen Z, Wang C, Zhang Q, Hong Q, He Y, et al. Resveratrol improves intestinal barrier function, alleviates mitochondrial dysfunction and induces mitophagy in diquat challenged piglets. Food Funct. 2019;10(1):344-54. https://doi.org/10.1039/c8fo02091d.

28. Huang Q, Xu W, Bai KW, He JT, Ahmad H, Zhou L, et al. Protective effects of leucine on redox status and mitochondrial-related gene abundance in the jejunum of intrauterine growth-retarded piglets during early weaning period. Arch Anim Nutr. 2017;71(2):93-107. https://doi.org/10.1080/ 1745039X.2017.1279712

29. Liu Y, Chen F, Odle J, Lin X, Jacobi SK, Zhu H, et al. Fish oil enhances intestinal integrity and inhibits TLR4 and NOD2 signaling pathways in weaned pigs after Ips challenge. J Nutr. 2012;142(11):2017-24. https://doi. org/10.3945/jn.112.164947.

30. Claus R, Gunthner D, Letzguss $H$. Effects of feeding fat-coated butyrate on mucosal morphology and function in the small intestine of the pig. J Anim Physiol Anim Nutr (Berl). 2007;91(7-8):312-8. https://doi.org/10.1111/j.14390396.2006.00655.x

31. Fasina YO, Moran ET, Ashwell CM, Conner DE, Leslie M, Mckee SR. Effect of dietary gelatin supplementation on the expression of selected enterocyte genes, intestinal development and early chick performance. Int J Poult Sci. 2007;6:944-51. https://doi.org/10.3923/ijps.2007.944.951.

32. Tappenden KA, Thomson A, Wild GE, McBurney MI. Short-chain fatty acidsupplemented total parenteral nutrition enhances functional adaptation to intestinal resection in rats. Gastroenterology. 1997;112(3):792-802. https:// doi.org/10.1053/gast.1997.v112.pm9041241.

33. Welter $\mathrm{H}$, Claus R. Expression of the monocarboxylate transporter 1 (mct1) in cells of the porcine intestine. Cell Biol Int. 2008;32(6):638-45. https://doi. org/10.1016/j.cellbi.2008.01.008.

34. Sepponen K, Ruusunen M, Pakkanen JA, Poso AR. Expression of cd147 and monocarboxylate transporters mct1, mct2 and mct4 in porcine small intestine and colon. Vet J. 2007;174(1):122-8. https://doi.org/10.1016/j.tvjl. 2006.05.015.

35. Thibault R, Blachier F, Darcy-Vrillon B, de Coppet P, Bourreille A, Segain JP. Butyrate utilization by the colonic mucosa in inflammatory bowel diseases: a transport deficiency. Inflamm Bowel Dis. 2010;16(4):684-95. https://doi. org/10.1002/ibd.21108.

36. Cuff MA, Lambert DW, Shirazi-Beechey SP. Substrate-induced regulation of the human colonic monocarboxylate transporter, mct1. J Physiol. 2002;539(Pt 2):361-71. https://doi.org/10.1113/jphysiol. 2001.014241.

37. Zhang S, Yang Q, Ren M, Qiao S, He P, Li D, et al. Effects of isoleucine on glucose uptake through the enhancement of muscular membrane concentrations of GLUTA and GLUT4 and intestinal membrane concentrations of Nat/glucose co-transporter 1 (SGLT-1) and GLUT2. Br J Nutr. 2016;116(4):593-602. https://doi.org/10.1017/ S0007114516002439.

38. Kaira K, Sunose Y, Arakawa K, Ogawa T, Sunaga N, Shimizu K, et al. Prognostic significance of L-type amino-acid transporter 1 expression in surgically resected pancreatic cancer. Br J Cancer. 2012;107(4):632-8. https:// doi.org/10.1038/bjc.2012.310
39. Dalmasso G, Nguyen HT, Yan Y, Charrier-Hisamuddin L, Sitaraman SV, Merlin D. Butyrate transcriptionally enhances peptide transporter PepT1 expression and activity. PLoS One. 2008;3(6):e2476. https://doi.org/10.1371/journal.pone. 0002476.

40. Mangian HF, Tappenden KA. Butyrate increases GLUT2 mRNA abundance by initiating transcription in Caco2-BBe cells. JPEN J Parenter Enteral Nutr. 2009; 33(6):607-17, 617. https://doi.org/10.1177/0148607109336599.

41. Glueck B, Han Y, Cresci G. Tributyrin supplementation protects immune responses and vasculature and reduces oxidative stress in the proximal colon of mice exposed to chronic-binge ethanol feeding. J Immunol Res. 2018;2018:9671919. https://doi.org/10.1155/2018/9671919.

42. Leonel AJ, Teixeira LG, Oliveira RP, Santiago AF, Batista NV, Ferreira TR, et al. Antioxidative and immunomodulatory effects of tributyrin supplementation on experimental colitis. Br J Nutr. 2013;109(8):1396-407. https://doi.org/10. 1017/S000711451200342X.

43. Meng Q, Guo T, Li G, Sun S, He S, Cheng B, et al. Dietary resveratrol improves antioxidant status of sows and piglets and regulates antioxidant gene expression in placenta by Keap1-Nrf2 pathway and Sirt1. J Anim Sci Biotechnol. 2018;9:34. https://doi.org/10.1186/s40104-018-0248-y.

44. Wang H, Chen Y, Zhai N, Chen X, Gan F, Li H, et al. Ochratoxin a-induced apoptosis of IPEC-J2 cells through ROS-mediated mitochondrial permeability transition pore opening pathway. J Agric Food Chem. 2017; 65(48):10630-7. https://doi.org/10.1021/acs.jafc.7b04434.

45. Pintana H, Sripetchwandee J, Supakul L, Apaijai N, Chattipakorn N, Chattipakorn S. Garlic extract attenuates brain mitochondrial dysfunction and cognitive deficit in obese-insulin resistant rats. Appl Physiol Nutr Metab. 2014;39(12):1373-9. https://doi.org/10.1139/apnm-2014-0255.

46. Zhou Y, Zhou L, Ruan Z, Mi S, Jiang M, Li X, et al. Chlorogenic acid ameliorates intestinal mitochondrial injury by increasing antioxidant effects and activity of respiratory complexes. Biosci Biotechnol Biochem. 2016;80(5): 962-71. https://doi.org/10.1080/09168451.2015.1127130.

47. Hong J, Jia Y, Pan S, Jia L, Li H, Han Z, et al. Butyrate alleviates high fat dietinduced obesity through activation of adiponectin-mediated pathway and stimulation of mitochondrial function in the skeletal muscle of mice. Oncotarget. 2016;7(35):56071-82. https://doi.org/10.18632/oncotarget.11267.

48. Li L, Wang HH, Nie XT, Jiang WR, Zhang YS. Sodium butyrate ameliorates lipopolysaccharide-induced cow mammary epithelial cells from oxidative stress damage and apoptosis. J Cell Biochem. 2018. https://doi.org/10.1002/ jcb. 27565.

49. Davis LM, Rho JM, Sullivan PG. Ucp-mediated free fatty acid uncoupling of isolated cortical mitochondria from fasted animals: correlations to dietary modulations. Epilepsia. 2008;49(Suppl 8):117-9. https://doi.org/10.1111/j. 1528-1167.2008.01854.x

50. West AP, Shadel GS. Mitochondrial DNA in innate immune responses and inflammatory pathology. Nat Rev Immunol. 2017;17(6):363-75. https://doi. org/10.1038/nri.2017.21.

51. Mikhed Y, Daiber A, Steven S. Mitochondrial oxidative stress, mitochondrial DNA damage and their role in age-related vascular dysfunction. Int J Mol Sci. 2015;16(7):15918-53. https://doi.org/10.3390/ijms160715918.

52. Chen J, Wong HS, Leong PK, Leung HY, Chan WM, Ko KM. Ursolic acid induces mitochondrial biogenesis through the activation of AMPK and PGC1 in C2C12 myotubes: a possible mechanism underlying its beneficial effect on exercise endurance. Food Funct. 2017:8(7):2425-36. https://doi.org/10. 1039/c7fo00127d

53. Picca A, Lezza AM. Regulation of mitochondrial biogenesis through TFAMmitochondrial DNA interactions: useful insights from aging and calorie restriction studies. Mitochondrion. 2015;25:67-75. https://doi.org/10.1016/j. mito.2015.10.001.

54. Hardie DG, Ross FA, Hawley SA. AMPK: a nutrient and energy sensor that maintains energy homeostasis. Nat Rev Mol Cell Biol. 2012;13(4):251-62. https://doi.org/10.1038/nrm3311.

55. Wu W, Wang S, Liu Q, Wang X, Shan T, Wang Y. Cathelicidin-WA attenuates LPS-induced inflammation and redox imbalance through activation of AMPK signaling. Free Radic Biol Med. 2018;129:338-53. https://doi.org/10. 1016/j.freeradbiomed.2018.09.045.

56. Kukidome D, Nishikawa T, Sonoda K, Imoto K, Fujisawa K, Yano M, et al. Activation of AMP-activated protein kinase reduces hyperglycemiainduced mitochondrial reactive oxygen species production and promotes mitochondrial biogenesis in human umbilical vein endothelial cells. Diabetes. 2006;55(1):120-7. https://doi.org/10.2337/diabetes.55.01. 06.db05-0943. 
57. Tang Y, Chen Y, Jiang H, Nie D. Short-chain fatty acids induced autophagy serves as an adaptive strategy for retarding mitochondria-mediated apoptotic cell death. Cell Death Differ. 2011;18(4):602-18. https://doi.org/10. 1038/cdd.2010.117.

58. Mollica MP, Mattace RG, Cavaliere G, Trinchese G, De Filippo C, Aceto S, et al. Butyrate regulates liver mitochondrial function, efficiency, and dynamics in insulin-resistant obese mice. Diabetes. 2017;66(5):1405-18. https://doi.org/10.2337/db16-0924.

Ready to submit your research? Choose BMC and benefit from:

- fast, convenient online submission

- thorough peer review by experienced researchers in your field

- rapid publication on acceptance

- support for research data, including large and complex data types

- gold Open Access which fosters wider collaboration and increased citations

- maximum visibility for your research: over $100 \mathrm{M}$ website views per year

At BMC, research is always in progress.

Learn more biomedcentral.com/submissions 